\title{
KUALITAS PELAYANAN PERGANTIAN STNK 5 TAHUN DI SAMSAT CIBADAK KABUPATEN SUKABUMI
}

\author{
SERVICE QUALITY OF 5 YEAR VEHICLE NUMBER \\ LETTER REPLACEMENT IN SAMSAT CIBADAK \\ SUKABUMI REGENCY
}

\author{
Ahmad Danial Fahad ${ }^{*}$, Beddy Iriawan Maksudi², Ginung Pratidina ${ }^{3}$ \\ 1,2,3Program Studi Administrasi Publik, Fakultas Ilmu Sosial dan Ilmu Politik, Universitas \\ Djuanda, Jl. Tol Ciawi No. 1, Kotak Pos 35, Bogor 16720 \\ *Korespondensi: Ahmad Danial Fahad. Email: danialfahad5@gmail.com
}

(Diterima: 22-05-2019; Ditelaah: 18-06-2019; Disetujui: 29-07-2019)

\begin{abstract}
Public service is a form of services provided by the bureaucracy or government to the community as the service user. Implementation of the public service is intended to fulfill the needs in accordance with the wants and expectations of the community. The purpose of this research is to find out the service quality provided by the civil servants in Samsat Cibadak Sukabumi Regency. The service quality can be measured on five dimensions, namely tangible, reliability, responsiviness, assurance, and empathy. This research uses the descriptive-quantitative methods. The population of this research is 1653 service user community and the sample is 96 respondents. Data is collected by using the observations, interviews and questionaires. Then, data is analysed by using the Weight Mean Score (WMS) to count the mean score. The result of this research indicates that the evaluation of respondents on the service quality in Samsat Cibadak Sukabumi Regency gains the mean score 3.8 categorized as good.
\end{abstract}

Keywords: Bureaucracy, Public Service, Service Quality.

\begin{abstract}
ABSTRAK
Pelayanan publik merupakan suatu bentuk layanan yang diberikan oleh birokrasi atau pemerintah kepada masyarakat. Pelaksanaan pelayanan publik bertujuan untuk memenuhi kebutuhan-kebutuhan yang sesuai dengan keinginan dan harapan masyarakat. Tujuan penelitian ini adalah untuk mengetahui kualitas pelayanan yang diberikan oleh petugas pelayanan yang ada di Samsat Cibadak Kabupaten Sukabumi. Kualitas pelayanan dapat diukur berdasarkan lima dimensi, yaitu tangible (bukti fisik), reliability (keandalan), responsiviness (ketanggapan), assurance (jaminan), dan empathy (perhatian). Penelitian ini menggunakan metode penelitian deskriptif-kuantitatif. Populasi penelitian adalah masyarakat pengguna layanan sebanyak 1.653 dan sampel penelitian ditentukan sebanyak 96 responden. Data dikumpulkan dengan cara observasi, wawancara dan penyebaran kuisioner/angket. Data dianalisis dengan menggunakan Weight Mean Score (WMS) untuk menghitung nilai rata-rata. Hasil penelitian menunjukkan bahwa penilaian kualitas pelayanan di Samsat Cibadak Kabupaten Sukabumi menghasilkan angka rata-rata sebesar 3,8 yang dikategorikan baik.
\end{abstract}

Kata Kunci: Birokrasi, Pelayanan Publik, Kualitas Pelayanan.

Ahmad Danial Fahad. 2019. Kualitas Pelayanan Pergantian STNK 5 Tahun di Samsat Cibadak Kabupaten Sukabumi. 


\section{PENDAHULUAN}

Pelayanan publik merupakan suatu bentuk layanan yang diberikan birokrasi/ pemerintah kepada masyarakat. Pelaksanaan pelayanan publik dimaksudkan untuk memenuhi kebutuhan-kebutuhan yang sesuai dengan keinginan dan harapan masyarakat. Karena pada hakekatnya pemerintah merupakan abdi masyarakat atau public servant. Sesuai dengan UU No. 25 Tahun 2009, pelayanan publik diartikan sebagai kegiatan atau rangkaian kegiatan dalam upaya memenuhi kebutuhan pelayanan yang sesuai dengan peraturan perundang-undangan bagi setiap warga negara atas barang dan jasa, maupun pelayanan administratif yang disediakan oleh penyelenggara pelayanan publik.

Sistem Administrasi Manunggal Satu Atap (Samsat) Cibadak Kabupaten Sukabumi merupakan salah satu instansi Pemerintah Daerah Kabupaten Sukabumi yang bertugas memberikan pelayanan publik berupa barang dan jasa secara langsung kepada masyarakat. Pembentukan Samsat Cibadak kabupaten Sukabumi dimaksudkan untuk memperlancar, mempermudah dan mempercepat pelayanan pajak kepada masyarakat. Samsat Cibadak Kabupaten Sukabumi merupakan suatu sistem kerjasama terpadu antara POLRI, Dinas Pendapatan Provinsi dan PT Jasa Raharja. Pelayanan di Samsat Cibadak kabupaten Sukabumi meliputi berbagai macam pelayanan/pengurusan pajak kendaraan bermotor. Jenis-jenis pengurusan pajak kendaraan bermotor diantara lain pelayanan untuk menerbitkan Surat Tanda Nomor Kendaraan Bermotor (STNK), Surat Tanda Coba Kendaraan Bermotor, Tanda Nomor Kendaraan Bermotor, Tanda Coba Kendaraan Bermotor dan Pemungutan Pajak Kendaraan Bermotor (PKB), Bea Balik Nama Kendaraan Bermotor (BBNKB) serta Sumbangan Wajib Dana Kecelakaan Lalu Lintas Jalan (SWDKLLJ).

Pengurusan pajak kendaraan bermotor merupakan kewajiban yang perlu dilakukan oleh pemilik kendaraan bermotor. Sebagai contoh perpanjangan STNK tahunan dan penggantian STNK lima tahunan sangat penting bagi pengendara kendaraan bermotor. Perpanjanagn STNK berkaitan dengan masa aktif/berlaku atau tidaknya STNK. Jika STNK yang dimiliki sudah habis masa berlakunya maka pengendara kendaraan bermotor dapat dikenakan sanksi. Hal ini senada dengan materi Undang-Undang Nomor 22 Tahun 2009 tentang Lalu Lintas dan Angkutan Jalan pasal 68 yang menjelaskan bahwa setiap kendaraan bermotor yang dioperasikan dijalan wajib dilengkapi dengan Surat Tanda Nomor Kendaraan (STNK) dan Tanda Nomor Kendaraan Bermotor (TNKB) yang masih berlaku. Bila pengendara mengemudikan kendaraan bermotor dengan STNK mati (sudah habis masa berlakunya) maka termasuk pelanggaran dan dapat dikenai sanksi administrative. Oleh karena itu, pengurusan pajak kendaraan bermotor perlu dilakukan.

Tabel 1. Jumlah Pemohon Pelayanan Pergantian STNK 5 Tahun Plat Kabupaten Sukabumi Tahunan di Samsat Cibadak

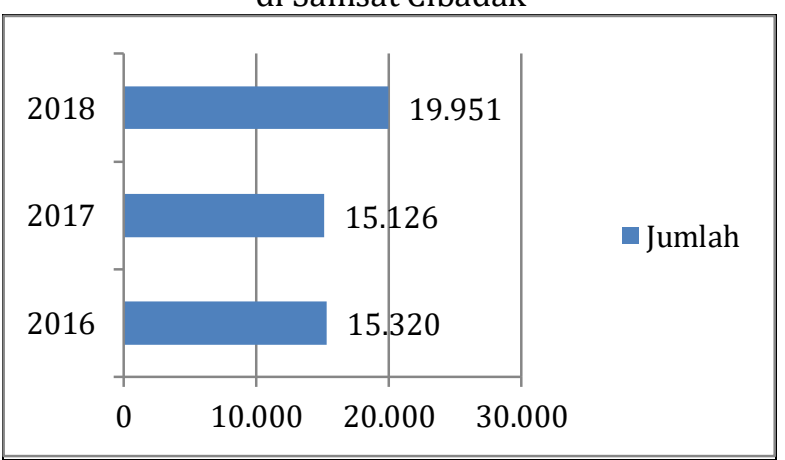

Data pada Tabel 1 di atas merupakan jumlah pemohon dari masyarakat yang melaksanakan pergantian STNK 5 Tahun di Samsat Cibadak dari 3 tahun terakhir. Standar Pelayanan proses pergantian STNK tersebut yaitu memakan waktu selama 35 menit dalam alur prosesnya

Dari proses pengesahan STNK 5 tahunan kendaraan bermotor di Samsat Cibadak Kabupaten Sukabumi hasil 
sementara observasi sementara dalam penelitian ini yang disimpulkan adalah:

1. Sesuai prosedur pergantian STNK 5 Tahunan tersebut yaitu memakan waktu selama 35 menit sebagai acuan yang ditetapkan di Samsat Cibadak, Namun dalam pelaksanaan prosesnya pelayanan tersebut tidak sesuai dengan waktu yang di tetapkan, hal tersebut disampaikan langsung oleh nara sumber yang sedang melaksanakan pergantian STNK 5 tahunan kendaraan milik pribadinya Ia datang dari jam 9.00 pagi namun baru beres mendapatkan TNKB baru jam 13.00, hal tersebut menunjukan bahwa ketepatan waktu pelayanan yang diberikan masih belum sesuai dengan apa yang telah ditetapkan di standar pelayanan Ganti STNK 5 tahunan.

2. Masih kurangnya fasilitas dalam hal ruang tunggu seperti kursi duduk khususnya di dalam proses pelayanan cek fisik dan penyerahan TNKB baru.

3. Kurangnya pendukung peralatan kerja dalam membantu petugas, hal tersebut terlihat dalam pembagia TNKB baru yang dimana petugas tidak menggunakan alat bantu pengeras suara agar masyarakat bisa mendengar lebih jelas.

\section{MATERI DAN METODE}

\section{Teori/Konsep yang Relevan}

Penelitian ini menggunakan teori dari Zeithaml, dkk tentang kualitas pelayanan (Hardiyansyah (2012: 46-47). Kualitas pelayanan (service quality) dapat diukur dari 5 dimensi, yaitu: tangible (bukti fisik), reliability (keandalan), responsiviness (ketanggapan), assurance (jaminan), dan empathy (perhatian).

Dimensi-dimensi kualitas pelayanan tersebut dapat digambarkan secara ringkas sebagai berikut:

1. Tangible (bukti fisik), berhubungan dengan penampilan fisik, peralatan, personil, dan media komunikasi.

2. Reliability (keandalan), menyangkut kemampuan dan keandalan untuk menyediakan pelayanan yang terpercaya.

3. Responsiveness (daya tanggap), berkaitan dengan kesanggupan untuk membantu dan menyediakan pelayanan secara tepat serta tanggap terhadap keinginan pengguna.

4. Assurance (jaminan), yaitu kemampuan dan keramahtamahan sopan santun pegawai dalam meyakinkan kepercayaan pengguna.

5. Empathy (perhatian), merupakan syarat untuk peduli, memberi perhatian secara personal dari pegawai kepada pengguna.

\section{Metode}

Metode penelitian dipandang sebagai cara ilmiah untuk mendapatkan data dengan tujuan dan kegunaan tertentu. Untuk memperolehnya, maka perlu digunakan metode tertentu. Peneliti menggunakan penelitian deskriptif (Sugiyono, 2012), yang bertujuan untuk menggambarkan tentang kualitas pelayanan.

Jumlah pengguna layanan Pergantian STNK 5 Tahun (populasi) di Samsat Cibadak Kabupaten Sukabumi sebanyak 1.653 orang (Data tersebut merupakan data pertahun 2018). Untuk menemukan sampel, peneliti menggunakan tingkat kesalahan $5 \%$ atau tingkat kepercayaan terhadap populasi sebesar 95\%, maka menentukan sampel peneliti menggunakan rumus sebagai berikut:

$$
\mathrm{n}=\frac{N}{N d^{2}+1}
$$

Keterangan:

$\mathrm{n}$ : jumlah sampel

N: Populasi

d: presisi.

Berdasarkan rumus di atas maka dapat diperoleh angka 96 sampel yang akan mengisi kuisioner yang dibagikan oleh peneliti. Untuk memperoleh data dari responden, maka peneliti menggunakan beberapa teknik pengumpulan data sebagai berikut: 
1. Observasi, yaitu pengumpulan data dengan cara mengamati, mencatat gejala-gejala yang tampak pada objek penelitian.

2. Wawancara, yaitu tanya-jawab secara terstruktur yang dilakukan oleh peneliti dalam rangka pengumpulan data dari responden (Sugiyono, 2012).

3. Kuesioner, yaitu pengumpulan data dengan cara menyebarkan angket kepada responden untuk memperoleh data yang diperlukan.

4. Studi pustaka, yaitu kajian yang bersumber dari buku, literatur, skripsi, dokumen, peraturan perundangundangan, dan media internet.

Teknik analisis data yang digunakan adalah menggambarkan jawaban-jawaban yang diberikan oleh responden dalam kuisioner. Data yang diperoleh melalui kuesioner diolah dengan menggunakan rumus Weight Means Score (WMS) sebagai berikut:

$$
M=\frac{\sum(\mathrm{fx})}{\mathrm{n}}
$$

Keterangan:

M: Perolehan penafsiran atau kriteria

F : Frekuensi jawaban

$\mathrm{X}$ : Pembobotan (skala nilai)

$\sum$ : Penjumlahan

$\mathrm{n}$ : Jumlah seluruh jawaban responden.

Tabel 2. Kriterian Penafsiran Angket

\begin{tabular}{ll}
\hline Interval Nilai & Kriteria Penafsiran \\
\hline $1,00-1,80$ & Sangat Tidak Baik \\
\hline $1,81-2,60$ & Tidak Baik \\
\hline $2,61-3,40$ & Cukup Baik \\
\hline $3,41-4,20$ & Baik \\
\hline $4,21-5,00$ & Sangat Baik \\
\hline
\end{tabular}

Sumber: Sugiyono (2012: 214)

Tabel 3. Penghitungan Rata-rata Item Pertanyaan

\begin{tabular}{llllll}
\hline No. & Alternatif jawaban & $\mathrm{x}$ & $\mathrm{f}$ & $\mathrm{f}(\mathrm{x})$ & $\mathrm{m}-\mathrm{f}(\mathrm{x}) / \mathrm{n}$ \\
\hline 1 & Sangat Baik & & & \\
\hline 2 & Baik & & & \\
\hline 3 & Cukup Baik & & & \\
\hline 4 & Tidak Baik & & & \\
\hline 5 & Sangat Tidak Baik & & \\
\hline
\end{tabular}

\section{HASIL DAN PEMBAHASAN}

Adapun hasil penelitian tentang kualitas pelayanan Pergantian STNK 5 Tahun di Samsat Cibadak Kabupaten Sukabumi berdasarkan uraian tiap dimensi dapat dilihat dalam pembahasan sebagai berikut:

Tabel 4. Rekapitulasi Jawaban Responden tentang Dimensi Tangible (Bukti Fisik)

\begin{tabular}{|c|c|c|c|}
\hline Dimensi & Indikator & $M$ & $\begin{array}{c}\text { Kriteria } \\
\text { Penafsiran }\end{array}$ \\
\hline \multirow{3}{*}{$\begin{array}{l}\text { Tangible } \\
\text { (Bentuk } \\
\text { Fisik) }\end{array}$} & $\begin{array}{l}\text { Ruang Tunggu } \\
\text { yang Nyaman }\end{array}$ & 3,7 & Baik \\
\hline & $\begin{array}{l}\text { Kerapihan } \\
\text { Penampilan } \\
\text { Petugas }\end{array}$ & 3,9 & Baik \\
\hline & $\begin{array}{l}\text { Penggunaan } \\
\text { Sistem } \\
\text { Komputerisasi }\end{array}$ & 4,2 & $\begin{array}{c}\text { Sangat } \\
\text { Baik }\end{array}$ \\
\hline \multicolumn{2}{|c|}{$\begin{array}{l}\text { Jumlah Rata-rata Angka } \\
\text { Penafsiran }\end{array}$} & 3,9 & Baik \\
\hline
\end{tabular}

Berdasarkan Tabel 4 dalam dimensi tangible (bukti fisik) dapat disimpulkan dari 3 indikator tersebut bahwa dimensi tangible (bukti fisik) sudah dalam kategori baik dengan nilai total 3,9. Nilai tersebut tentunya bukan berarti dimensi tersebut sudah sempurna akan tetapi juga ada beberapa kekurangan apabila responden benar-benar mengkritisi atas indikator yang telah dijawab.

Tabel 5. Rekapitulasi Jawaban Responden tentang Dimensi Reliability (Keandalan)

\begin{tabular}{llcc}
\hline Dimensi & Indikator & M & $\begin{array}{c}\text { Kriteria } \\
\text { Penafsiran }\end{array}$ \\
\hline $\begin{array}{l}\text { Reability } \\
\text { (Keandalan) }\end{array}$ & Ketepatan & 3,4 & Baik \\
& $\begin{array}{l}\text { Waktu } \\
\text { Pelayanan }\end{array}$ & & \\
\cline { 2 - 3 } & Kejelasan & 3,6 & Baik \\
& Informasi \\
& Persyaratan & & \\
& Pelayanan & & \\
\cline { 2 - 3 } & Petugas & 3,8 & Baik \\
& Memiliki & & \\
& $\begin{array}{l}\text { Pengetahuan } \\
\text { Menjawab }\end{array}$ & & \\
& Pertanyaan & & \\
& Pengguna & & \\
\hline Jumlah Rata-rata Angka & 3,6 & Baik \\
Penafsiran & & & \\
\hline Sumber: Hasil Penelitian, 2019 & &
\end{tabular}


Berdasarkan Tabel 5 tentang dimensi reliability (keandalan) yang disimpulkan dari 3 indikator tersebut, masyarakat pengguna menilai bahwa dimensi tersebut sudah dinilai baik dengan nilai total 3,6. Namun berdasarkan wawancara peneliti dengan masyarakat masih adanya keluhan waktu yang sangat dirasa masih lama dalam proses pergantian STNK 5 Tahun di Samsat Cibadak.

Tabel 6. Rekapitulasi Jawaban Responden tentang Dimensi Responsiveness (Daya Tanggap)

\begin{tabular}{llcc}
\hline Dimensi & Indikator & M & $\begin{array}{c}\text { Keriteria } \\
\text { Penafsiran }\end{array}$ \\
\hline $\begin{array}{l}\text { Respon- } \\
\text { siveness } \\
\text { (Daya }\end{array}$ & $\begin{array}{l}\text { Petugas membantu } \\
\text { manggaparakat dalam }\end{array}$ & 4 & Baik \\
& $\begin{array}{l}\text { memberiakan infor- } \\
\text { masi yang benar }\end{array}$ & & \\
\cline { 2 - 4 } & $\begin{array}{l}\text { Petugas sudah men- } \\
\text { jalankan standar } \\
\text { pelayanan minimal }\end{array}$ & & Baik \\
& $\begin{array}{l}\text { Kecermatan petugas } \\
\text { dalam memberikan } \\
\text { informasi }\end{array}$ & & \\
& 3,9 & Baik \\
\hline $\begin{array}{l}\text { Jumlah Rata-rata Angka } \\
\text { Penafsiran }\end{array}$ & 4 & Baik \\
\hline Sumber: Hasil Penelitian, 2019 & & \\
\hline
\end{tabular}

Berdasarkan Tabel 6 dalam dimensi tentang responsiveness (daya tanggap) dapat disimpulkan dari 3 indikator tersebut, masyarakat pengguna menilai bahwa dimensi tersebut sudah dinilai baik dengan nilai total 4 dengan kategori baik sesuai angka penafsiran. Maka dari pada itu dapat disimpulkan bahwa petugas pelayanan ganti STNK 5 tahunan di Samsat Cibadak Kabupaten Sukabumi memiliki daya tanggap yang baik.

Tabel 7. Rekapitulasi Jawaban Responden tentang Assurance (Jaminan)

\begin{tabular}{llcc}
\multicolumn{3}{c}{ tentang Assurance (Jaminan) } \\
\hline Dimensi & Indikator & $\mathrm{M}$ & $\begin{array}{c}\text { Keriteria } \\
\text { Penafsiran }\end{array}$ \\
\hline $\begin{array}{l}\text { Assurance } \\
\text { (Jaminan) }\end{array}$ & $\begin{array}{l}\text { Kemudahan } \\
\text { dalam menemui } \\
\text { petugas }\end{array}$ & 4,1 & Baik \\
\cline { 2 - 4 } & $\begin{array}{l}\text { Jujur dalam } \\
\text { memberikan } \\
\text { pelayanan }\end{array}$ & 4,2 & Baik \\
\multicolumn{1}{l}{ Jumlah Rata-rata Angka } & 4,1 & Baik \\
Penafsiran & & \\
\hline
\end{tabular}

Sumber: Hasil Penelitian, 2019
Berdasarkan rekapitulasi hasil Tabel 7 tentang dimensi assurance (jaminan) dapat disimpulkan dari 2 indikator tersebut, masyarakat pengguna menilai bahwa dimensi tersebut sudah dikategorikan baik dengan nilai total 4,1 dengan kategori baik sesuai dengan angka penafsiran. Dari indikator tersebut disimpulkan bahwa petugas telah memberikan jaminan bagi masyarakat pengguna dalam segi kemudahan dalam menemui petugas serta menjamin masyarakat bahwa petugas memberikan pelayanan telah sesuai dengan aturan tidak meminta uang tambahan kepada masyarakat.

Tabel 8. Rekapitulasi Jawaban Responden tentang Empathy (Perhatian)

\begin{tabular}{clcc}
\hline Dimensi & Indikator & $\mathrm{M}$ & $\begin{array}{c}\text { Kriteria } \\
\text { Penafsiran }\end{array}$ \\
\hline Empaty & $\begin{array}{l}\text { Keramahan } \\
\text { petugas dalam } \\
\text { memberikan } \\
\text { pelayanan }\end{array}$ & 3,9 & Baik \\
\cline { 2 - 4 } & $\begin{array}{l}\text { Mengargai } \\
\text { Setiap } \\
\text { pemohon }\end{array}$ & 4 & Baik \\
\hline $\begin{array}{l}\text { Jumlah Rata-rata Angka } \\
\text { Penafsiran }\end{array}$ & 3,9 & Baik \\
Sumber: Hasil Penelitian, 2019 & & \\
\hline
\end{tabular}

Berdasarkan rekapitulasi hasil Tabel 8 dari dimensi empathy (perhatian) dapat disimpulkan dari 2 indikator tersebut, masyarakat pengguna telah menilai bahwa dimensi tersebut sudah dikategorikan baik dengan skor 3,9 sesuai dengan angka penafsiran. Indikator tersebut menggambarkan bahwa petugas telah mampu memberikan sikap ramah dengan baik terhadap setiap masyarakat yang datang untuk melaksanakan Pergantian STNK 5 tahunan di Samsat Cibadak.

Hasil pembahasan tentang kualitas pelayanan ganti STNK 5 Tahun di Samsat Cibadak Kabupaten Sukabumi sebagaimana direkapitulasi pada Tabel 9 di atas menunjukkan skor 3,9 sesuai dengan angka penafsiran dikategorikan baik. 
Tabel 9. Rekapitulasi dari Hasil Kualitas

Pelayanan Ganti STNK 5 Tahun di Samsat Cibadak Kabupaten Sukabumi

\begin{tabular}{|c|c|c|c|}
\hline Dimensi & Indikator & $\mathrm{M}$ & $\begin{array}{c}\text { Kriteria } \\
\text { Penafsiran }\end{array}$ \\
\hline \multirow[t]{3}{*}{ Tangible } & $\begin{array}{l}\text { Ruang tunggu yang } \\
\text { nyaman }\end{array}$ & 3,7 & Baik \\
\hline & $\begin{array}{l}\text { Kerapihan penam- } \\
\text { pilan petugas }\end{array}$ & 3,9 & Baik \\
\hline & $\begin{array}{l}\text { Penggunaan sistem } \\
\text { komputerisasi }\end{array}$ & 4,2 & Baik \\
\hline \multicolumn{2}{|c|}{ Rekapitulasi } & 3,9 & Baik \\
\hline \multirow[t]{3}{*}{$\begin{array}{l}\text { Relia- } \\
\text { bility }\end{array}$} & $\begin{array}{l}\text { Ketepatan waktu } \\
\text { pelayanan }\end{array}$ & 3,4 & Baik \\
\hline & $\begin{array}{l}\text { Kejelasan mengenai } \\
\text { persyaratan } \\
\text { pelayanan }\end{array}$ & 3,6 & Baik \\
\hline & $\begin{array}{l}\text { Petugas memiliki } \\
\text { pengetahuan } \\
\text { untuk menjawab } \\
\text { pertanyaan } \\
\text { pengguna }\end{array}$ & 3,8 & Baik \\
\hline \multicolumn{2}{|c|}{ Reakapitulasi } & 3,6 & Baik \\
\hline \multirow[t]{3}{*}{$\begin{array}{l}\text { Respon- } \\
\text { siveness }\end{array}$} & $\begin{array}{l}\text { Petugas membantu } \\
\text { masyarakat dalam } \\
\text { memberikan infor- } \\
\text { masi yang benar }\end{array}$ & 4 & Baik \\
\hline & $\begin{array}{l}\text { Petugas sudah } \\
\text { menjalankan } \\
\text { standar pelayanan } \\
\text { minimal }\end{array}$ & 4 & Baik \\
\hline & $\begin{array}{l}\text { Kecermatan petu- } \\
\text { gas dalam membe- } \\
\text { rikan informasi } \\
\text { paling terbaru }\end{array}$ & 3,9 & Baik \\
\hline \multicolumn{2}{|c|}{ Rekapitulasi } & 4 & Baik \\
\hline \multirow[t]{2}{*}{ Assurance } & $\begin{array}{l}\text { Kemudahan dalam } \\
\text { menemui petugas } \\
\text { pelayanan }\end{array}$ & 4,1 & Baik \\
\hline & $\begin{array}{l}\text { Jujur dalam mem- } \\
\text { berikan pelayanan }\end{array}$ & 4,2 & Baik \\
\hline \multicolumn{2}{|c|}{ Rekapitulasi } & 4,1 & Baik \\
\hline \multirow[t]{2}{*}{ Empathy } & $\begin{array}{l}\text { Keramahan petu- } \\
\text { gas dalam membe- } \\
\text { rikan pelayanan }\end{array}$ & 3,9 & Baik \\
\hline & $\begin{array}{l}\text { Menghargai setiap } \\
\text { pemohon }\end{array}$ & 4 & Baik \\
\hline \multicolumn{2}{|c|}{ Rekapitulasi } & 3,9 & Baik \\
\hline \multicolumn{2}{|c|}{ Jumlah keseluruhan } & 3,9 & Baik \\
\hline
\end{tabular}

Sumber: Hasil Penelitian, 2019

\section{KESIMPULAN DAN REKOMENDASI}

\section{Kesimpulan}

Berdasarkan hasil penelitian tentang kualitas pelayanan pergantian STNK 5 Tahun di Samsat Cibadak, maka dapat disimpukan hal-hal sebagai berikut:

1. Dilihat dari keseluruhan hasil analisis kualitas pelayanan, maka sudah dikategorikan baik. Rekapitulasi lima dimensi kualitas pelayanan (tangible, reliability, responsiveness, assurance, dan empathy) menunjukkan skor 3,9 yang termasuk ke dalam kriteria baik.

2. Untuk skor tertinggi terdapat pada dimensi assurance tepatnya pada dimensi jujur dalam memberikan pelayanan. Oleh sebab itu, masyarakat merasa terjamin terhadap petugas akan kejujuran khususnya dalam hal biaya proses pergantian STNK 5 tahunan di Samsat Cibadak telah sesuai dengan apa yang ditetapkan dengan tidak ada biaya tambahan yang diminta oleh petugas pelayanan.

3. Untuk skor terendah terdapat pada dimensi reliability, tepatnya pada dimensi ketepatan waktu pelayanan. Hal tersebut dirasakan masyarakat masih kurang cepatnya petugas dalam menyelesaikan proses pergantian STNK 5 tahunan.

4. Hambatan-hambatan yang muncul dalam memberikan pelayanan yang maksimal ada pada waktu penyelesaian pelayanan proses pergantian STNK 5 tahunan yang dirasakan oleh beberapa masyarakat masih kurang cepat sehingga perlu adanya perbaikan dalam meningkatkan kualitas pelayanan itu sendiri.

\section{Rekomendasi}

Berdasarkan hasil penelitian tersebut, peneliti memberikan beberapa saran sebagai berikut:

1. Perlu adanya peningkatan kualitas pelayanan dalam segi waktu dimana peningkatan tersebut dapat mengakibatkan rasa tingkat penilaian masyarakat terhadap kualitas pelayanan proses pergantian STNK 5 tahunan di Samsat Cibadak Kabupaten Sukabumi.

2. Perlu penambahan sarana alat bantu pengeras suara dalam menjalankan diprosesnya pembagian TNKB baru 
sehingga masyarakat yang menunggu lebih mendengar apabila nama masyarakat tersebut dipanggil oleh petugas.

3. Perlu peningkatan sarana dan prasana ruang tunggu yang nyaman sehingga masyarakat merasa nyaman dalam melaksanakan proses pelayanan pergantian STNK 5 Tahun di Samsat Cibadak.

\section{DAFTAR PUSTAKA}

\section{Buku:}

Hardiyansyah. 2011. Kualitas Pelayanan Publik, Konsep, Dimensi, Indikator dan Implementasinya. Yogyakarta: Gava Media.

Sugiono. 2012. Metode Penelitian Administrasi. Bandung: Alfabeta.

\section{Dokumen:}

Laporan Kantor Samsat Cibadak Kabupaten Sukabumi tentang Data Pemohon Layanan Ganti STNK 5 Tahun (Tahun 2016, 2017, 2018).

\section{Peraturan Perundang-undangan:}

Undang-Undang Nomor 25 Tahun 2009 tentang Pelayanan Publik.

Peraturan Daerah Jawa Barat Nomor 7 Tahun 2002 tentang Sisa Perhitungan Anggaran Pendapatan dan Belanja Daerah Tahun Anggaran 2001. 